Karstenia 54: 9-13, 2014

\title{
Chlorostroma vestlandicum sp. nov., a host-specific mycoparasite on Hypoxylon vogesiacum from western Norway
}

\author{
BJÖRN NORDÉN, THOMAS LÆSSØE and JOHN BJARNE JORDAL
}

\begin{abstract}
NORDÉN, B., LÆSSØE, T. \& JORDAL, J. B. 2014: Chlorostroma vestlandicum sp. nov., a host-specific mycoparasite on Hypoxylon vogesiacum from western Norway Karstenia 54: 9-13. HELSINKI. ISSN 0453-3402.

The new species Chlorostroma vestlandicum is described from coarse dead wood of Ulmus glabra in western Norway. It was invariably found in close association with Hypoxylon vogesiacum and appears to be mycoparasitic on this species. With a strikingly orange entostroma, tiny perithecia and specialized habitat association it is a highly distinctive species. $C$. vestlandicum differs from the type species by the color of the entostroma (bright yellow orange as opposed to ochraceous), iodine reaction of the apical apparatus, ascospores (more or less ellipsoid as opposed to more or less cuboid). The surface is not green or bluegreen as in the previously described species, albeit dark greenish blackish in section. Its distribution seems to cover mainly the hemiboreal regions of western Norway, an area not yet affected but threatened by Dutch elm disease. It is probably a rare species restricted to the most dead wood rich sites with big populations of $H$. vogesiacum.
\end{abstract}

Key words: Xylariales, stromatic, pyrenomycete, temperate deciduous forest, coarse woody debris, Ulmus glabra.

Björn Nordén, Norwegian Institute for Nature Research NINA, Gaustadalléen 21, N-0349 Oslo, Norway, e-mail: Bjorn.Norden@nina.no. Corresponding author.

Thomas Laessøe, Department of Biology/Natural History Museum of Denmark, Universitetsparken 15,2100 KøbenhavnØ,Denmark, e-mail: thomasl@bio.ku.dk

John Bjarne Jordal, Auragata 3, N-6600 Sunndalsøra, Norway, e-mail: john.bjarne.jordal@sunndals.net

\section{Introduction}

In western Norway many areas of semi-natural forests still remain, protected from forestry by the steep topography amidst fjords and mountains. Elm (Ulmus glabra Huds.) is often a dominating tree species in these forests and the area is not yet affected by the Dutch elm disease. Left after previous land-use as woodlands with pollarding and grazing, many of the elms are old and large, but now start to die and produce a lot of dead wood. During a largescale survey of the biodiversity of these forests, we repeatedly encountered a black undulating stromatic pyrenomycete, up to $2-3 \mathrm{~cm}$ wide, with beautiful, orange interior on dead wood of 
U. glabra (Fig. 1). The stromata were found on top of or very close to stromata of Hypoxylon vogesiacum (Pers.) Sacc. (Xylariaceae), on which it appears to be parasitic. Our material show clear morphological affinities to Chlorostroma subcubisporum A.N. Mill., Lar.N. Vassiljeva \& J.D. Rogers described by Miller et al. (2007), and we therefore place our new species in the genus Chlorostroma A.N. Mill., Lar.N. Vassiljeva \& J.D. Rogers. Both previously described species of Chlorostroma are, as well as our species, associated with Hypoxylon stromata (Miller et al. 2007, Læssøe et al. 2010).

\section{Material and methods}

Material of the new species was collected during a survey of old temperate deciduous trees in Norway as a part of the project 'Areas for red-listed species - survey and monitoring' (ARKO). Microscopic material was studied in water, in 5\% Lugol's and Melzer's solutions and in $10 \% \mathrm{KOH}$ in order to reveal any color reactions. We attempted to culture the species but failed and we did not obtain sufficiently convincing DNA results from direct sequencing of the content of perithecia. Colors are coded with Kornerup \& Wanscher (1975).

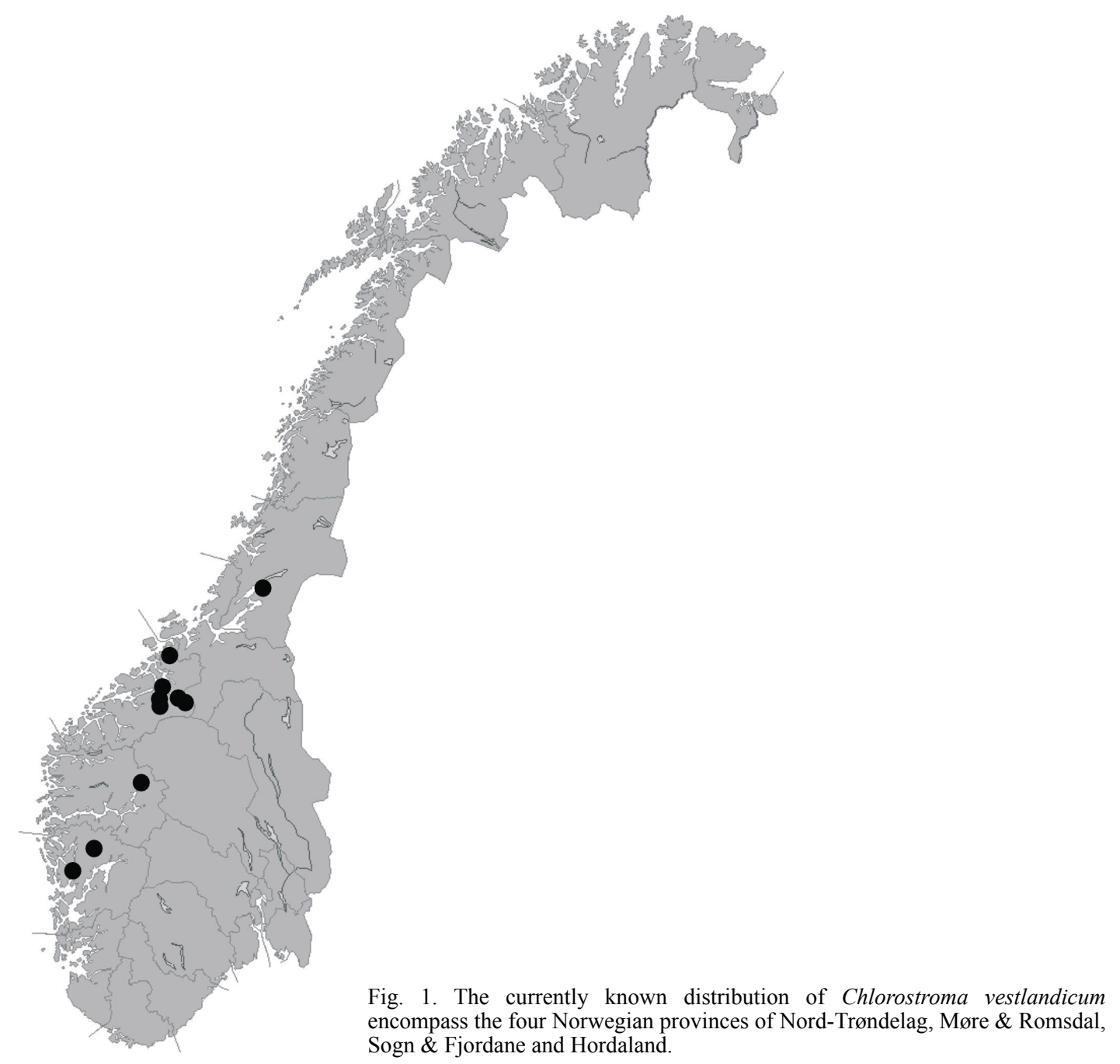
Sogn \& Fjordane and Hordaland. 


\section{Results}

Chlorostroma vestlandicum B. Nordén \& Læssøe, sp. nova - Fig. 1

MycoBank: MB 808158.

Holotype: Norway. Møre og Romsdal. Sunndal, Knutsliøyan, broadleaved forest, on Hypoxylon vogesiacum on fallen trunks of pollarded Ulmus glabra, 8'45'9"'- 8'45'22'"E, 62 38'34" - 62'38'36"N, alt. 90-100 m, 08.V.2012 Nordén \& Jordal (O-F 74998).

Stromata found close to (up to a few $\mathrm{cm}$ from) or on top of stromata of Hypoxylon vogesiacum on dead wood, peltate-pulvinate, $1-2-3 \mathrm{~cm}$ in diam, black. Surface undulating, without perithecial contours. Ostioles rarely visible, ca $20 \mu \mathrm{m}$ in diam, light brownish grey to black, flat to slightly papillate. Endostroma solid or with a small hollow in the middle, buff to greenish yellow (3B7) to bright yellow orange (6A8), without color reaction in $\mathrm{KOH}$. Ectostroma 140-200 thick $(\mathrm{n}=3)$, dark greenish blackish in section, extractable pigments in $10 \% \mathrm{KOH}$ dark green (29D6). Perithecia globose, ellipsoid or pyriform, height $133-174-215(\mathrm{n}=10)$, neck up to 150 $\mu \mathrm{m}$ long. Peridium not carbonized, olivaceous. Asci 121-129-137 × 9.8-10.2-10.6 $\mu \mathrm{m}(\mathrm{n}=10)$, spore-bearing part $66-72-78 \mu \mathrm{m}(\mathrm{n}=10)$, stipe 60-68-77 $\mu \mathrm{m}$. Apical apparatus more or less blue in Lugol's and Melzer's solutions, width $1.7-2.5-3.3 \mu \mathrm{m} \quad(\mathrm{n}=10)$, height $0.2-0.3-0.4$ $\mu \mathrm{m}(\mathrm{n}=10)$. Paraphyses sparse, filiform, longcelled, rarely branched, width 3.6-4.1-4.6 $\mu \mathrm{m}$. Ascospores sooty olive brown, broadly ellipsoid, mostly equilateral but sometimes with one more flattened side, unicellular from the beginning, lacking a perispore, with two guttules, length 9.110.1-11.1 $\mu \mathrm{m}$, width 4.4-4.9-5.4 $\mu \mathrm{m}(\mathrm{n}=31)$, the lowermost spore in each ascus slightly longer: length 9.9-11.2-12.5 $\mu \mathrm{m}$, width 4.5-4.8-5.1 $\mu \mathrm{m}(\mathrm{n}=10)$. Germ slit not prominent, straight, 2.3-2.9-3.5 $\mu \mathrm{m}(\mathrm{n}=11)$. Traces of anamorph resembling a Geniculisporium found on immature stromata, olivaceous green, becoming bluegreen (25D6) in $\mathrm{KOH}$.
Etymology: vestlandicum, from Vestlandet (western Norway).

C. vestlandicum differs from the type species by the color of the entostroma (bright yellow orange as opposed to ochraceous), iodine reaction of the apical apparatus, ascospores (more or less ellipsoid as opposed to more or less cuboid). The surface is not green or bluegreen as in the previously described species, albeit dark greenish blackish in section. The habitat and distribution also differs (associated with $H$. vogesiacum in western Norway vs. associated with Hypoxylon perforatum (Schwein.) Fr. in North Carolina). Chlorostroma cyaninum Læssøe, Srikit. \& J. Fourn. has rather cuboid spores, a buff surface with the underlaying blue colour just visible. It is tropical like Hypoxylon aeruginosum J.H. Mill., which could also belong in Chlorostroma (Læssøe et al. 2010). The latter also differ in the internal coloration and in the blue pigmented surface. None of these species are known from cultures despite of repeated attempts to cultivate them from freshly collected material (Miller et al. 2007, Læssøe et al. 2010).

The species was found on wood of Ulmus glabra; on coarse logs of old trees or on coarse fallen branches, or on dead parts of still living trees, always associated with stromata of $H$. vogesiacum. All findings were made in deciduous forests dominated by U. glabra (and sometimes Fraxinus excelsior), at a height of up to 250 meters above sea level. The exposition of the slopes was mostly between South and West. The presently known distribution of $C$. vestlandicum (Fig. 2) covers the hemiboreal vegetation zone of western Norway with the vegetation sections O3 (highly oceanic) to OC (indifferent between oceanic and continental) (Moen 1999, Bakkestuen et al. 2008). The species (like its host) thus seems to prefer relatively warm summers, but shows no clear affinity to oceanic or continental climate. 


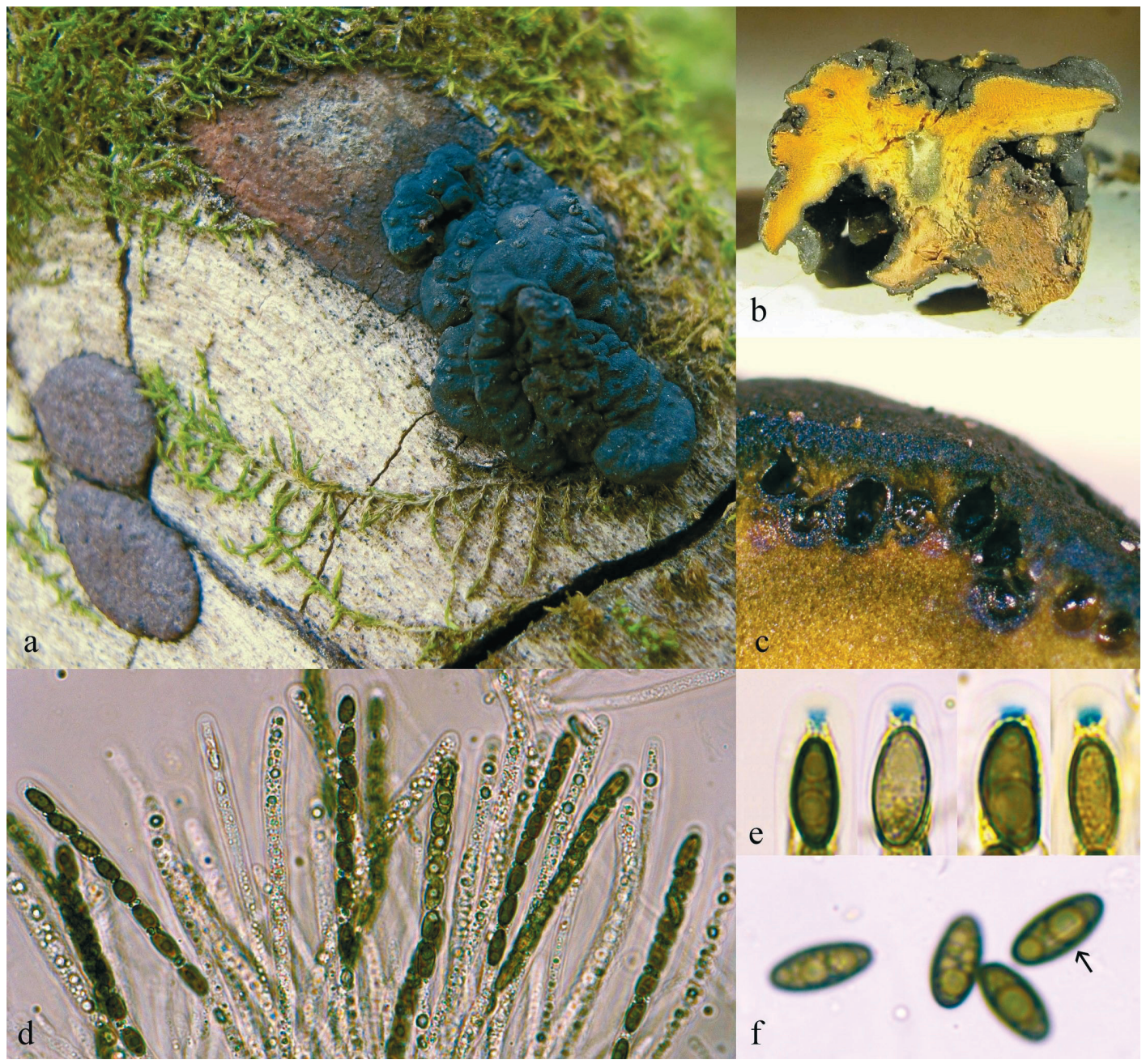

Fig. 2. Chlorostroma vestlandicum (holotype). a = stroma (pulvinate, black) on top of, and adjacent to, stromata of Hypoxylon vogesiacum (effused, purplish gray) on a log of Ulmus glabra, $\mathrm{b}=$ section through stroma showing yellow orange interior, $\mathrm{c}=$ close-up of section showing perithecial layer, $\mathrm{d}=$ asci with ascospores, in water, $\mathrm{e}=$ ascal apices with amyloid apical apparatus, $\mathrm{f}=$ ascospores in water, arrow indicates germination slit.

Additional material studied (all from broadleaved/deciduous forest or pastures on $U$. glabra with $H$. vogesiacum): NORWAY. Hordaland. Samnanger, by Skardsvatnet,

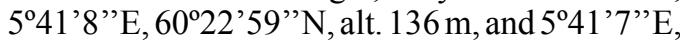
$60^{\circ} 22^{\prime} 54^{\prime}$ 'N, alt.91 m,23.V.2013 Nordén \&Jordal (O-F74999, O-F75000); Voss, Sandbrekkene in Teigdalen, 6० 7' $45^{\prime}$ 'E, $60^{\circ} 42^{\prime}$ ' $48^{\prime}$ 'N, alt. 235 m, 12.V.2014 Nordén \& Jordal (O-F75025). Møre og Romsdal. Aure, Todalen, 8०44'3' E, $63^{\circ} 12^{\prime} 51^{\prime \prime} \mathrm{N}$, alt. $102 \mathrm{~m}, 12 . \mathrm{V} .2012$ Nordén \& Jordal (O-F75001); Nesset, Eikesdalen,

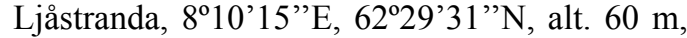
11. X.2011 Nordén \& Jordal (O-F75008); Nesset,

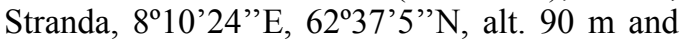
$8^{\circ} 10^{\prime} 20^{\prime \prime} \mathrm{E}, 62^{\circ} 37^{\prime} 2^{\prime \prime} \mathrm{N}$, alt. $53 \mathrm{~m}, 22 . \mathrm{V} .2012$ Jordal (O-F75002, O-F75003); Sunndal, Knutsliøyan, 8'45'22'”E, 62³8'34'N , alt. 95 m, 17.X.2011, Jordal (O-F75009); Fale, 852'55'E, 62'37'34”'N, alt. 125 m, 27.VIII.2013, Gaarder (O-F75010); Grøvla, 8 54' 46”'E, 62 36'33'”N, alt. 155 m, 20.VII.2013, Gaarder (O-F75011); Tingvoll, Fjøseid, 8 $8^{\circ} 17^{\prime} 15^{\prime \prime} \mathrm{E}, \quad 62^{\circ} 48^{\prime} 41^{\prime \prime} \mathrm{N}$, alt. $190 \mathrm{~m}$ and $8^{\circ} 17^{\prime} 23^{\prime \prime} \mathrm{E}, 62^{\circ} 48^{\prime} 42^{\prime \prime} \mathrm{N}$, 
alt. $250 \mathrm{~m}, 20 . \mathrm{I} .2013$ Gaarder (O-F75007). Nord-Trøndelag. Steinkjer, Byahalla nature reserve, $11^{\circ} 34^{\prime} 19^{\prime \prime} \mathrm{E}, 64^{\circ} 3$ ' 3" $\mathrm{N}$, alt. $170 \mathrm{~m}$, 09.V.2014 Nordén, Jordal \& Holien (O-F75026). Sogn og Fjordane. Luster, Hyrnavollen, 7³7'42”'E, 61'32'49”'N, alt. 105 m, 14.VI.2012 Nordén \& Jordal (O-F75012).

\section{Discussion}

Based on many similarities with the type species C. subcubisporum (Miller et al. 2007), we think our new species is best be placed in Chlorostroma. Striking similarities include the general habit and coloration of stromata, the small perithecia, few paraphyses present, and the association with Hypoxylon stromata. Obtaining DNA from this fungus appears to be challenging (as with C. subcubisporum; Miller et al. 2007), and we did not succeed despite repeated attempts. Culturing attempts were also fruitless and a possible explanation for this may be the mycoparasitic nature of $C$. vestlandicum and the other species of Chlorostroma. We suggest that shooting spores of $C$. vestlandicum onto cultures of $H$. vogesiacum should be tested as a method to stimulate spore germination. Although Chlorostroma probably belongs to the Xylariales, its phylogenetic position within this order is based on indirect evidence (Miller et al. 2007), and is in need of further study.

There is little doubt that the new species is closely associated with $H$. vogesiacum and its distribution is probably partly delimited by the distribution of its fungal host. $H$. vogesiacum was described from the Vosges mountains in the NE corner of France. It is, furthermore, known from Sweden, Finland, Austria, Switzerland, and Spain as well as from North America and Asia. $H$. vogesiacum has a hemiboreal distribution in the Nordic countries (Granmo et al. 1989), and has not been found in for example Denmark or in the UK. In Norway $H$. vogesiacum is widely distributed in the warmest parts of southern Norway north to Trøndelag, with its largest populations in western Norway. It mainly grows on Ulmus and occasionally on Fraxinus in parts of Europe including Sweden and Norway. Since C. vestlandicum is a prominent species and should have been described earlier if widely distributed in Europe, we hypothesize that it has a narrower distribution than its host, possibly defined by climatic factors. It should be searched for in other areas with a similar climate in Europe. U. glabra on which it occurs, and its apparent host species $H$. vogesiacum are both nationally red-listed in Norway (both as NT; Kålås et al. 2010) and declining, and the new species should therefore warrant attention in conservation work in Norway.

Acknowledgements: Mikako Sasa (Novozymes) is thanked for making attempts to get our species into culture and Mika Bendiksby and Marie Davey for attempting to extract DNA. Geir Gaarder is thanked for placing collected material at our disposal. The Norwegian Environment Agency enabled the fieldwork, and the Norwegian Biodiversity Information Centre financed the taxonomic work. Ernest Emmett is thanked for checking the English language.

\section{References}

Bakkestuen, V., Erikstad, L. \& Halvorsen, R. 2008: Stepless models for regional environmental variation in Norway. - Journal of Biogeography 35: 1906-1922.

Kålås, J.A., Viken, Å., Henriksen, S. \& Skjelseth, S. (eds) 2010: The 2010 Norwegian Red List for Species. - Norwegian Biodiversity Information Centre. Trondheim.

Kornerup, A. \& Wanscher, J. H. 1981: Taschenlexicon der Farben. - Muster-Schmidt Verlag. Zürich \& Göttingen.

Læssøe, T., Srikitikulchai, P., Fournier, J., Köpcke, B. \& Stadler, M. 2010: Lepraric acid derivatives as chemotaxonomic markers in Hypoxylon aeruginosum, Chlorostroma subcubisporum and C. cyaninum, sp. nov. - Fungal Biology 114: 481-489.

Miller, A.N., Vasiljeva, L.N. \& Rogers, J.D. 2007: Chlorostroma subcubisporum gen. et sp. nov. and notes on the systematic position of Thuemenella cubispora. - Sydowia 59: 138-147.

Moen, A. 1999: National Atlas of Norway: Vegetation. Norwegian Mapping Authority. Hønefoss. 